\title{
EFFECTS OF GRAIN SIZE ON THE DYNAMIC RECRYSTALLIZATION OF 25Cr2Ni4MoV STEEL FOR A SUPER-LARGE NUCLEAR-POWER ROTOR
}

\author{
VPLIV VELIKOSTI KRISTALNIH ZRN NA DINAMIČNO \\ REKRISTALIZACIJO JEKLENE ZLITINE 25Cr2Ni4MoV ZA \\ OGROMNI ROTOR JEDRSKE ELEKTRARNE
}

\author{
Li-yan Ye, Yue-wen Zhai*, Le-yu Zhou, Xiao-mao He, Peng Jiang \\ Beijing Research Institute of Mechanical and Electrical Technology, Science and Technology Development and Innovation Center, 18 Xueqing \\ Road, Haidian District, Beijing 100083, P. R. China \\ Prejem rokopisa - received: 2019-11-17; sprejem za objavo - accepted for publication: 2020-03-23
}

doi:10.17222/mit.2019.281

\begin{abstract}
The effects of grain size on the dynamic recrystallization of $25 \mathrm{Cr} 2 \mathrm{Ni} 4 \mathrm{MoV}$ steel for a super-large nuclear-power rotor were investigated on a Gleeble-1500 thermal-mechanical simulation tester with the temperature range of $1373 \mathrm{~K}-1523 \mathrm{~K}$ and the strain rate range of $0.005-0.5 \mathrm{~s}^{-1}$. It was found that the flow stresses with fine grains are greater than those with coarse grains under certain deformation conditions. At high temperatures and strain rates, the DRX of the alloy with coarse grains is complete, while that of the alloy with fine grains is incomplete. In particular, the smallest DRX grain size is about $22 \mu \mathrm{m}$. The reconstituted microstructure by DRX with an initial grain size of $22 \mu \mathrm{m}$ shows no refinement. Finally, it can be deduced that the model can precisely predict the rate of DRX for $25 \mathrm{Cr} 2 \mathrm{Ni} 4 \mathrm{MoV}$ steel by comparing experimental results and predicted results about the flow stress.
\end{abstract}

Keywords: $25 \mathrm{Cr} 2 \mathrm{Ni} 4 \mathrm{MoV}$ steel, flow stress, grain size, dynamic recrystallization

Avtorji članka so raziskovali vpliv velikosti kristalnih zrn na dinamično rekristalizacijo jekla $25 \mathrm{Cr} 2 \mathrm{Ni4} \mathrm{MoV}$ za zelo velik rotor $\mathrm{v}$ jedrski elektrarni. Raziskave so izvajali na termo-mehanskem preizkuševalniku Gleeble-1500 v temperaturnem območju med $1373 \mathrm{~K}$ in $1523 \mathrm{~K}$ ter hitrostih deformacije med $0,005 \mathrm{~s}^{-1}$ in $0,5 \mathrm{~s}^{-1}$. Ugotovili so, da je meja tečenja pri zlitini z drobnejšimi kristalnimi zrni višja, kot pri grobo zrnati mikrostrukturi zlitine za dane pogoje deformacije. Pri višji temperaturi in hitrosti deformacije je dinamična rekristalizacija grobozrnate zlitine potekla popolnoma medtem, ko je bila pri finozrnati zlitini nepopolna. Najmanjša velikost kristalnih zrn po dinamični rekristalizaciji je bila okoli 22 um. Pri zlitini z začetno velikostjo zrn $22 \mu \mathrm{m}$ ni prišlo do udrobitve, t.j. zmanjšanja velikosti kristalnih zrn, po njeni dinamični rekristalizaciji. Avtorji v zaključku še ugotavljajo, da so z izdelanim modelom lahko natančno predvideli obseg dinamične rekristalizacije zlitine $25 \mathrm{Cr} 2 \mathrm{Ni} 4 \mathrm{MoV}$ in napovedali njeno mejo tečenja $\mathrm{v}$ primerjavi z dejanskimi eksperimentalnimi rezultati.

Ključne besede: jeklena zlitina $25 \mathrm{Cr} 2 \mathrm{Ni} 4 \mathrm{MoV}$, meja tečenja, velikost kristalnih zrn, dinamična rekristalizacija

\section{INTRODUCTION}

A super-large nuclear-power rotor with the largest diameter of 3 metres is produced by open die forging at high temperature from a large cast ingot of about 650 tons. Owing to the super-large size, during the open-die forging, the majority of the rotor is always at a high temperature of no less than $1373 \mathrm{~K}$ and inhomogeneous deformation with strain rate of no more than $0.5 \mathrm{~s}^{-1}$. The movements of tools during open-die forging as one kind of discontinuous and local forming process are clarified into three main categories. Taking the drawing process of the round billet, for example, the top die strikes the workpiece, the top die feeds along the axial direction without touching the workpiece, and the manipulator rotates the workpiece. Three movements are alternated according to open-die forging schedule. ${ }^{1,2}$ Correspondingly, for a certain part of the workpiece, dynamic recovery (DRV), metadynamic recrystallization (MDRX) or static

*Corresponding author's e-mail:

yeliyan2006@sina.com (Zhai Yue-wen) recrystallization (SRX) can happen before the dynamic recrystallization (DRX), which results in different initial grain sizes for the DRX and makes the microstructure evolution of DRX complex. ${ }^{3}$ For example, the initial grain size of the area with DRV is about $2 \mathrm{~mm}$, while the initial grain size of the area with complete SRX is quite small. Due to the severe service environment, a superlarge nuclear-power rotor has strict requirements on microstructure and properties. $25 \mathrm{Cr} 2 \mathrm{Ni} 4 \mathrm{MoV}$ has great potential for super-large nuclear-power rotors. According to the Hall-Petch relationship, the yield stress increases with the inverse square root of the grain size, which leads to fine-grain strengthening. ${ }^{4}$ DRX with a different initial grain size might reconstitute the microstructure with different levels of fine grain. Therefore, to obtain the desired property, it is important to quantitatively investigate the influence of the initial grain size on the evolution of the DRX microstructure.

In recent years, many studies have been conducted to investigate the hot-deformation behaviour of metals and alloys. ${ }^{5-10}$ For example, W. Wang and J. Zhao ${ }^{11}$ deduced 
Table 1: Chemical compositions of steel $25 \mathrm{Cr} 2 \mathrm{Ni} 4 \mathrm{MoV}(w / \%)$

\begin{tabular}{|c|c|c|c|c|c|c|c|c|c|c|}
\hline $\mathrm{C}$ & $\mathrm{Mn}$ & $\mathrm{P}$ & $\mathrm{S}$ & $\mathrm{Si}$ & $\mathrm{Ni}$ & $\mathrm{Cr}$ & $\mathrm{Mo}$ & $\mathrm{V}$ & $\mathrm{Cu}$ & $\mathrm{Fe}$ \\
\hline $\mathrm{F} \leq 0.3$ & $0.1 \approx 0.3$ & $\leq 0.015$ & $\leq 0.015$ & $\leq 0.012$ & $2.0 \approx 2.5$ & $2.15 \approx 2.45$ & $0.6 \approx 0.85$ & $\leq 0.12$ & $\leq 0.17$ & $\mathrm{Bal}$. \\
\hline
\end{tabular}

kinematic models of DRX to describe the dynamic recrystallization behaviour of $20 \mathrm{Cr} 2 \mathrm{Ni} 4 \mathrm{~A}$ steel, and a dynamic recrystallization grain size model of 20Cr2Ni4A steel was also constructed. D. L. Sang and R. D. $\mathrm{Fu}^{12}$ investigated the dynamic microstructure evolution and mechanism of the Fe-38Mn alloy during hot deformation. It was found that the degree of the recrystallization increased with the deformation temperature and strain rate, and the occurrence temperature of full DRX decreased with increasing strain rate. W. Wang and R. $\mathrm{Ma}^{13}$ established a kinetic model and a kinematic model of DRX for 40CrNiMo. Y. K. Xu and P. Birnbaum ${ }^{14}$ proposed a JMAK-type DRX kinetic and dynamic recrystallization grain size model for $22 \mathrm{MnB} 5$ steel. A larger deformation degree is needed for a completed DRX of 22MnB5 steel when the deformation temperature is decreased or the strain rate is increased. P. Zhou and Q. X. $\mathrm{Ma}^{15}$ studied the dynamic recrystallization behaviour of as-cast $30 \mathrm{Cr} 2 \mathrm{Ni} 4 \mathrm{MoV}$ steel and determined the kinetics model of the DRX. As one kind of potential material for super-large nuclear-power rotors, the DRX of $25 \mathrm{Cr} 2 \mathrm{Ni} 4 \mathrm{MoV}$ steel needs to be further studied to guide the design of the open-die forging process. In this paper, the rate and the progress of DRX with initial grain sizes of $22 \mu \mathrm{m}$ and $1970 \mu \mathrm{m}$ was discussed respectively during hot-compression tests.

\section{EXPERIMENTAL MATERIALS AND PROCEDURES}

The chemical composition of the $25 \mathrm{Cr} 2 \mathrm{Ni} 4 \mathrm{MoV}$ steel studied in this work is shown in Table 1. Based on the possible manufacturing practice of the alloy, two kinds of specimens are obtained. One is annealed samples with a grain size of $22 \mu \mathrm{m}$. The other is held for $2 \mathrm{~h}$ at $1523 \mathrm{~K}$ with a grain size of $1970 \mu \mathrm{m}$. Compression specimens with a diameter of $10 \mathrm{~mm}$ and a length of $12 \mathrm{~mm}$ were machined from each heat-treatment alloy billet for hot-compression tests on Gleeble-1500 thermal mechanical simulation tester. As shown in Figure 1, the

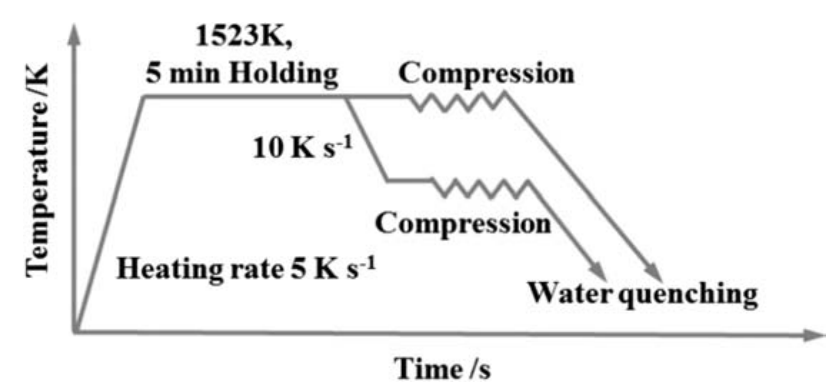

Figure 1: Experiment scheme of hot compression

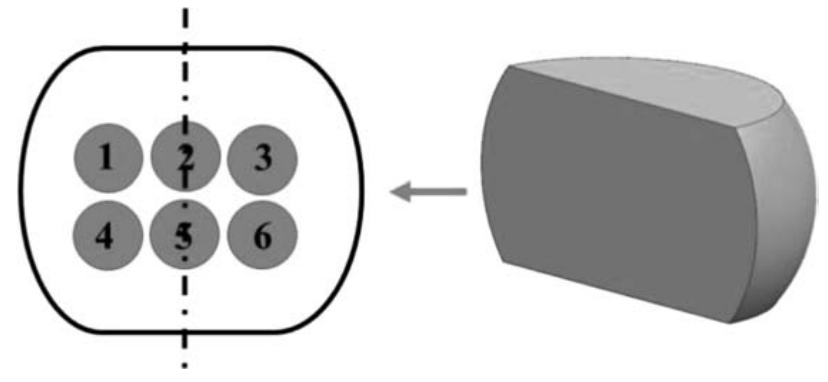

Figure 2: Six positions at the sliced section for the optical microstructure observation

specimens were heated to $1523 \mathrm{~K}$ at a heating rate of $10 \mathrm{~K} / \mathrm{s}$ and held for 5 minutes to achieve a homogeneous austenitic microstructure, then cooled to the deformation temperature at a rate of $10 \mathrm{~K} / \mathrm{s}$ and held for 1 minute. In order to minimize the effect of friction, graphite sheets as the lubricant material were applied to both ends of the specimen.

Four different forming temperatures (1373, 1423, 1473 , and 1523) $\mathrm{K}$ and three strain rates $(0.005,0.05$, $0.5) \mathrm{s}^{-1}$ were used in the hot compression tests. All the specimens were compressed to a true strain of $90 \%$, and then water quenched to room temperature to keep the austenite structure after DRX. Finally, the quenched specimens were sliced parallel to the axial direction, polished and etched using saturation picric for optical microscopic observation. As shown in Figure 2, the average grain sizes for six positions at the sliced section were measured according to ASTM standards.

\section{RESULTS AND DISCUSSION}

\subsection{Hot-deformation flow curves}

Figure 3 shows a number of true stress-strain curves with initial grain size of $22 \mu \mathrm{m}$ and $1970 \mu \mathrm{m}$. The signs c and $f$ represent coarse and fine grains, respectively. It is obvious that the initial grain size strongly influences the flow curves. At high temperature $(T \geq 1473 \mathrm{~K})$ and high strain rate $\left(\dot{\varepsilon} \geq 0.5 \mathrm{~s}^{-1}\right)$, specimens with coarse grains show typical DRX flow stress, including a single peak followed by a steady state, while specimens with fine grains show no single peak, which indicates DRX is incomplete. It is because dislocation movements including gliding and sliding are inhibited more strongly in fine grains than in coarse grains. When the temperature and strain rate are constant, stress increases with decreasing grain size, resulting in a behaviour similar to that described by the Hall-Petch equation. The largest peak stress difference between two kinds of specimen is $12 \mathrm{MPa}$, while steady stress difference is $7 \mathrm{MPa}$. 

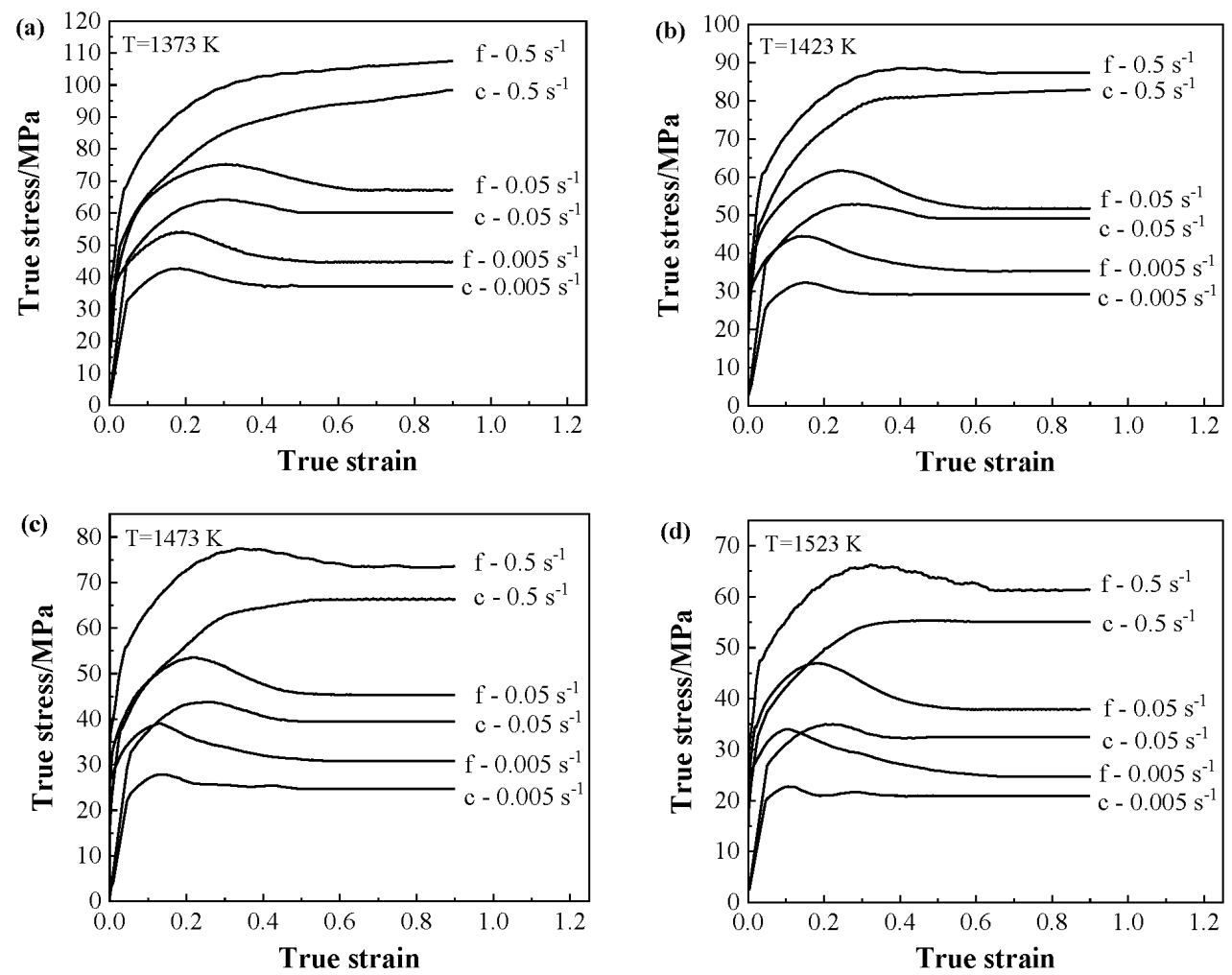

Figure 3: True stress-strain curves obtained at different temperatures: a) $1373 \mathrm{~K}$, b) $1423 \mathrm{~K}$, c) $1473 \mathrm{~K}$, d) $1523 \mathrm{~K}$

\subsection{DRX microstructure}

Figures 4 and $\mathbf{5}$ shows the optical microstructures at the central area of the section (around the position 5 in Figure 2) with a strain rate of $0.05 \mathrm{~s}^{-1}$ and temperatures of $(1373,1423,1473$, and 1523) K, respectively. DRX happens completely for all the specimens at a strain rate of $0.05 \mathrm{~s}^{-1}$ as indicated by the flow curves. For an initial grain size of $22 \mu \mathrm{m}$, the average grain sizes (obtained from the positions 1 to 6 in Figure 2) are $38.0 \mu \mathrm{m}, 49.2$ $\mu \mathrm{m}, 63.8 \mu \mathrm{m}$ and $71.4 \mu \mathrm{m}$ for the deformation temperatures of $(1373,1423,1473$, and 1523), respectively. For
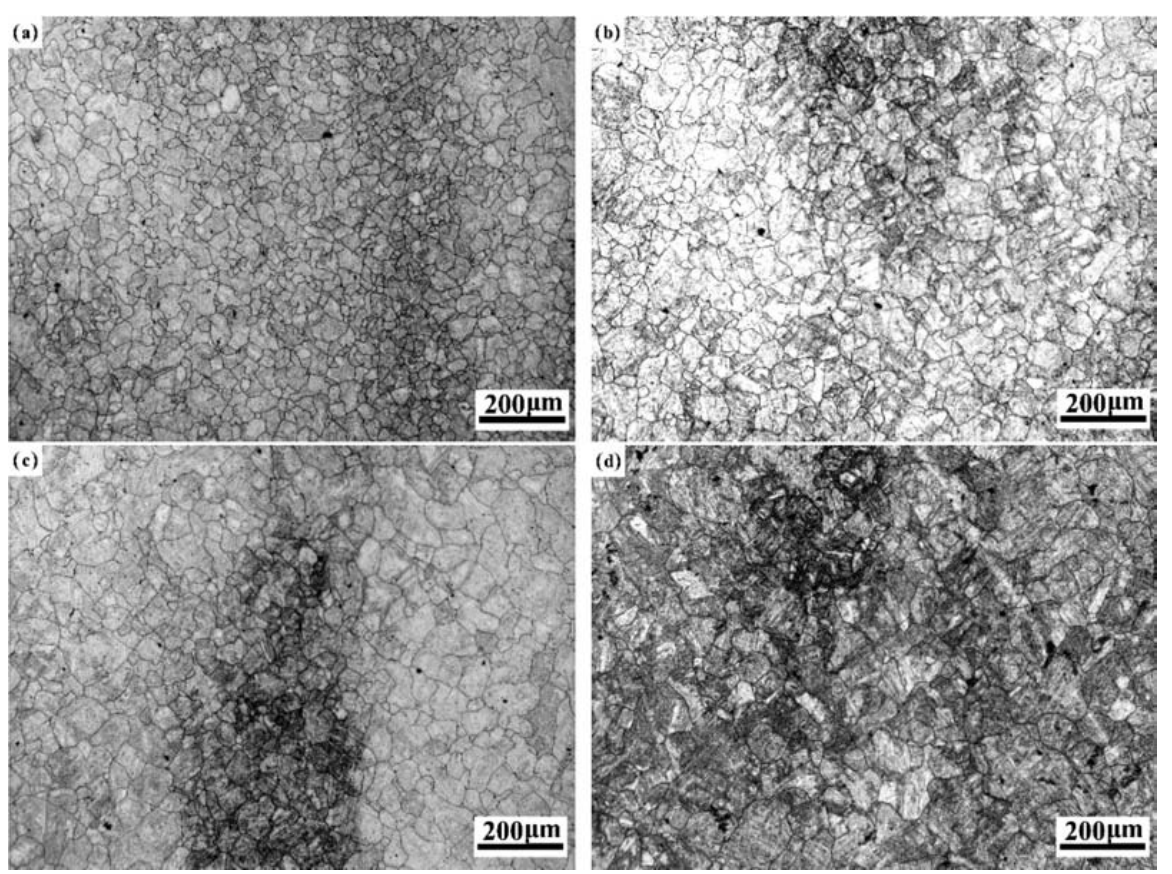

Figure 4: Optical microstructures of $25 \mathrm{Cr} 2 \mathrm{Ni} 4 \mathrm{MoV}$ steel after dynamic recrystallization at a true strain of 0.9 and a strain rate of $0.05 \mathrm{~s}^{-1}$ for an initial grain size of $22 \mu \mathrm{m}$ with different temperatures: a) $1373 \mathrm{~K}$, b) $1423 \mathrm{~K}$, c) $1473 \mathrm{~K}$, d) $1523 \mathrm{~K}$ 

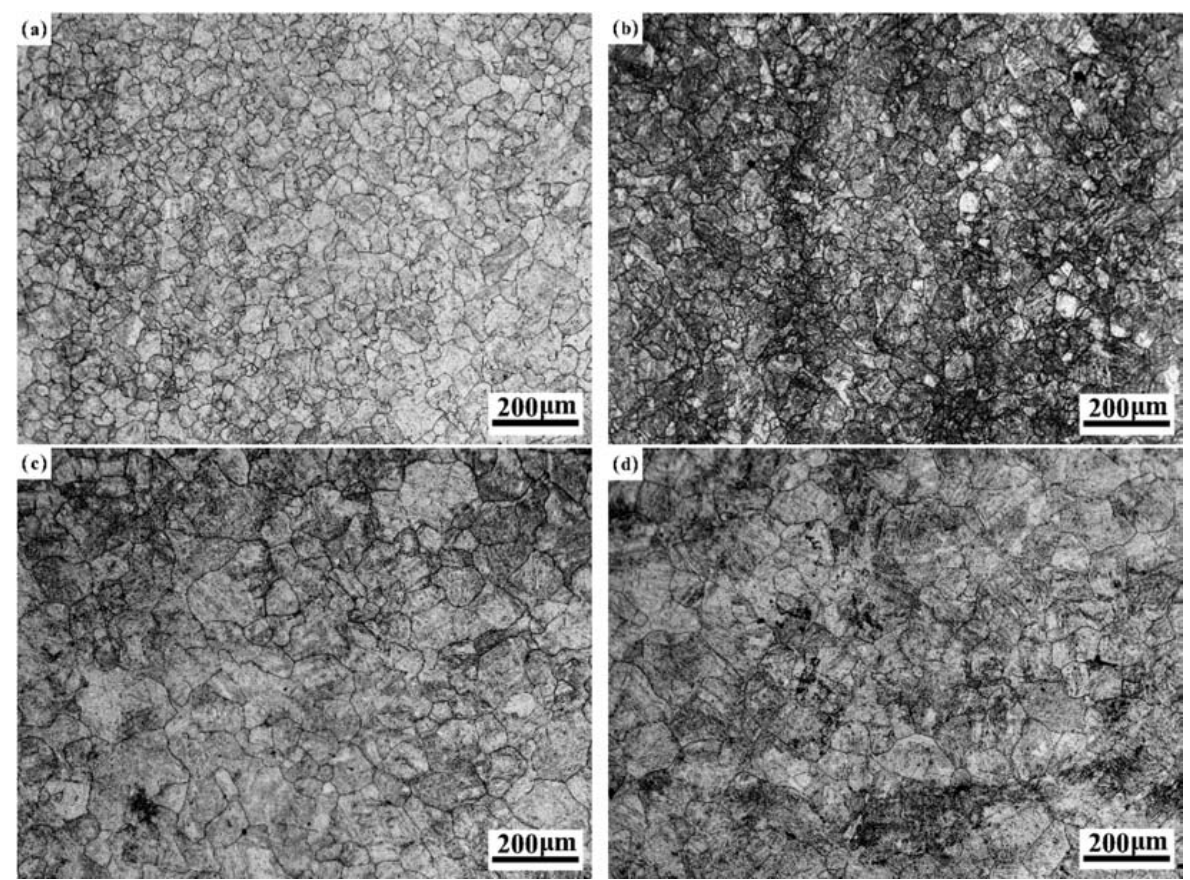

Figure 5: Optical microstructures of $25 \mathrm{Cr} 2 \mathrm{Ni} 4 \mathrm{MoV}$ steel after dynamic recrystallization at a true strain of 0.9 and a strain rate of $0.05 \mathrm{~s}^{-1}$ for an initial grain size of $1970 \mu \mathrm{m}$ at different temperatures: a) $1373 \mathrm{~K}$, b) $1423 \mathrm{~K}$, c) $1473 \mathrm{~K}$, d) $1523 \mathrm{~K}$

an initial grain size of $1970 \mu \mathrm{m}$, the average grain sizes (obtained from the positions 1 to 6 in Figure 2) are about $45.2 \mu \mathrm{m}, 50.2 \mu \mathrm{m}, 97.1 \mu \mathrm{m}$, and $100.5 \mu \mathrm{m}$, respectively. It can be concluded that the dynamic recrystallization grain size decreases with decreasing temperature when the initial grain size is constant. It can be explained that grain growth instead of grain nucleation dominates the microstructure evolution of DRX at high temperature.
The dynamic recrystallization grain size increases with increasing initial grain size for a certain temperature. It is mentioned above that a fine initial grain has more grain boundaries for nucleation.

Figures $\mathbf{6}$ and $\mathbf{7}$ show the optical microstructures in the central area of the section (around the position 5 in Figure 2) with a temperature of $1523 \mathrm{~K}$ and strain rates of $(0.005,0.05$, and 0.5$) \mathrm{s}^{-1}$, respectively. For an initial
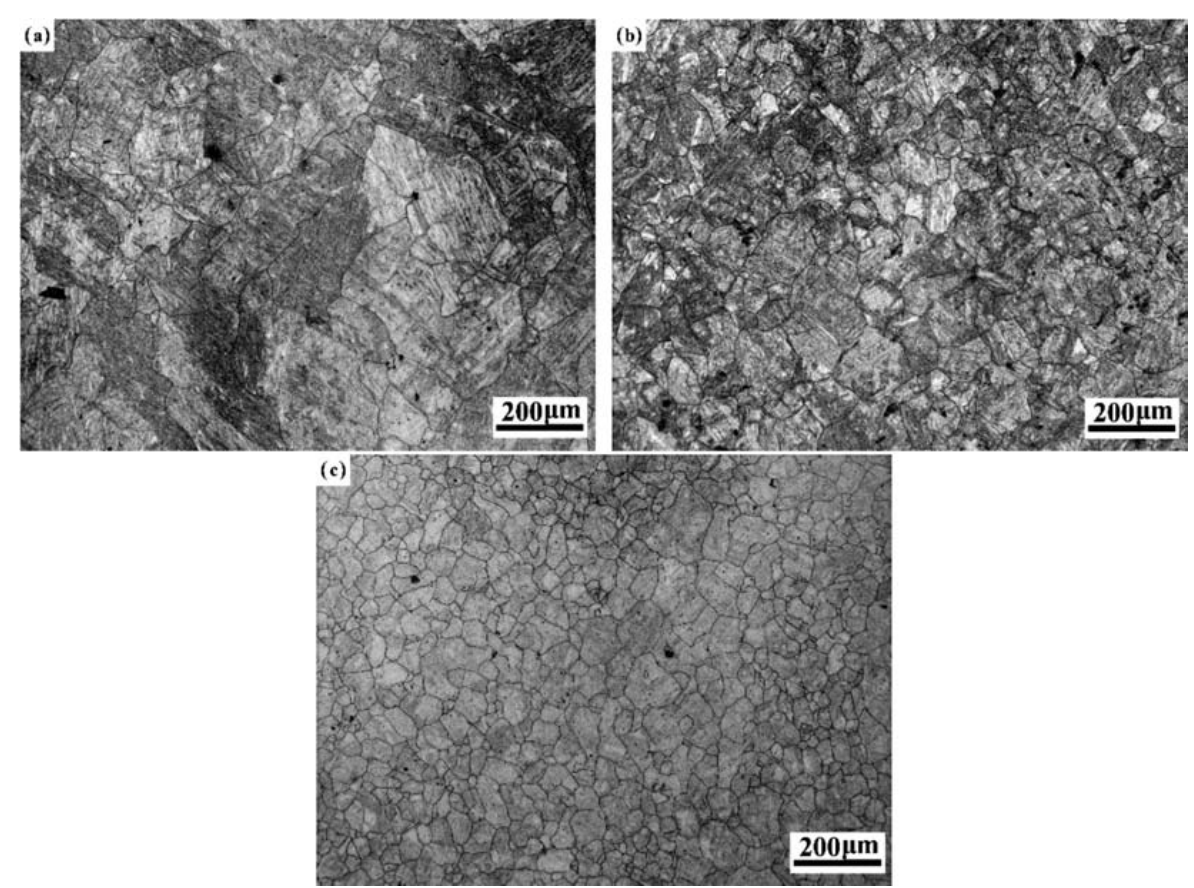

Figure 6: Optical microstructures of $25 \mathrm{Cr} 2 \mathrm{Ni} 4 \mathrm{MoV}$ steel after dynamic recrystallization at $1523 \mathrm{~K}$ and a true strain of 0.9 for an initial grain size of $22 \mu \mathrm{m}$ with different strain rates: a) $0.005 \mathrm{~s}^{-1}$, b) $0.05 \mathrm{~s}^{-1}$, c) $0.5 \mathrm{~s}^{-1}$ 

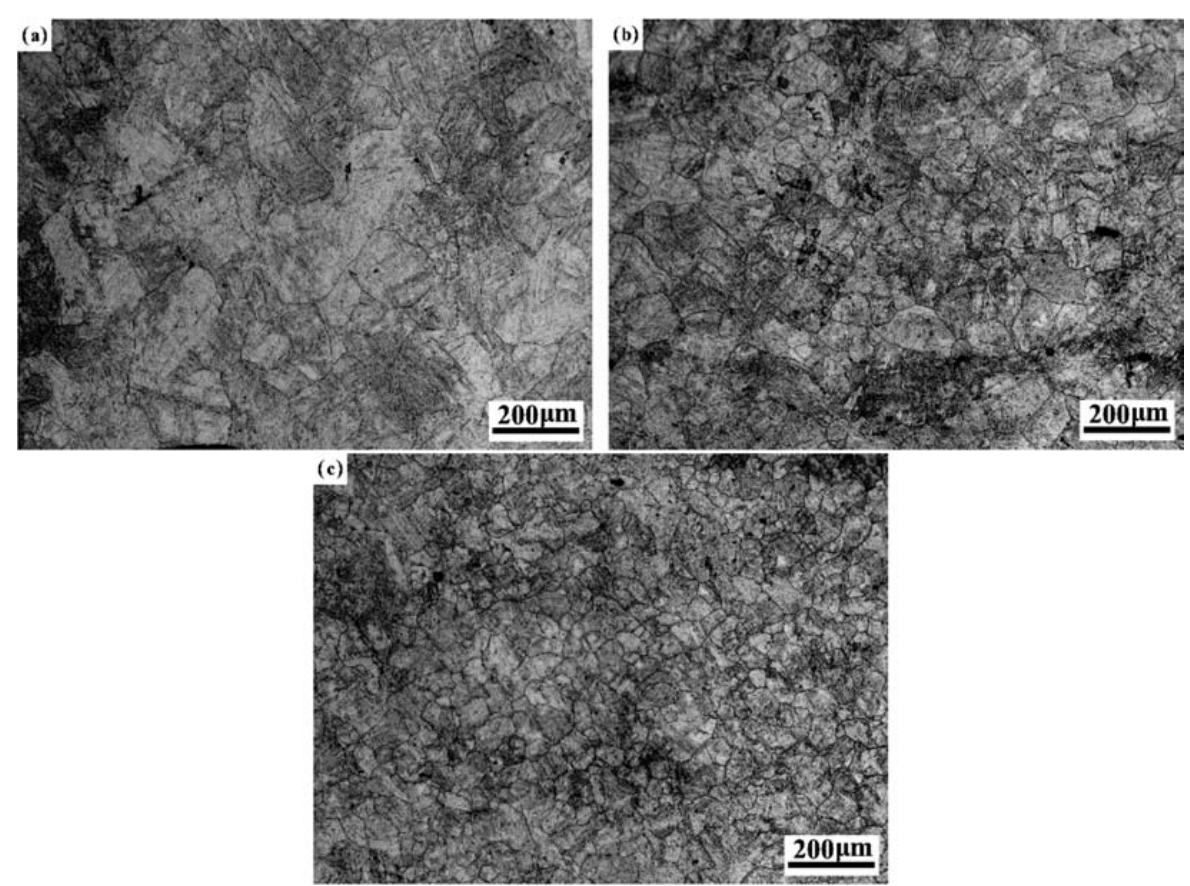

Figure 7: Optical microstructures of $25 \mathrm{Cr} 2 \mathrm{Ni} 4 \mathrm{MoV}$ steel after dynamic recrystallization at $1523 \mathrm{~K}$ and a true strain of 0.9 for an initial grain size of $1970 \mu \mathrm{m}$ with different strain rates: a) $0.005 \mathrm{~s}^{-1}$, b) $0.05 \mathrm{~s}^{-1}$, c) $0.5 \mathrm{~s}^{-1}$

grain size of $22 \mu \mathrm{m}$, the average grain sizes (obtained from the positions 1 to 6 in Figure 2) are $155.5 \mu \mathrm{m}, 71.4$ $\mu \mathrm{m}$ and $40.6 \mu \mathrm{m}$ for the strain rate of $(0.005,0.05$, and $0.5) \mathrm{s}^{-1}$, respectively. For an initial grain size of $1970 \mu \mathrm{m}$, the average grain sizes (obtained from the positions 1 to 6 in Figure 2) are $157.6 \mu \mathrm{m}, 100.5 \mu \mathrm{m}$, and $60.3 \mu \mathrm{m}$, respectively. Therefore, the average grain size decreases with increasing strain rate for a certain temperature and initial grain size. It can be clarified from two aspects. On the one hand, dynamic recovery during the work-hardening period consumes less distortion energy, then more energy was dissipated to DRX nucleation. On the other hand, higher strain rates mean less time for recrystallized grains to grow.

The average dynamic recrystallization grain sizes are summarized in Table 2. When the dynamic recrystallization grain is larger, the difference in the dynamic recrystallization grain size resulting from different initial grain sizes is also larger and the maximum difference is $47.3 \mu \mathrm{m}$ with the domain of $1473 \mathrm{~K} / 0.005 \mathrm{~s}^{-1}$. The smaller dynamic recrystallization grain size gap is achieved when the dynamic recrystallization grain is finer. Though at the deformation condition of $1373 \mathrm{~K} /$ $0.5 \mathrm{~s}^{-1}$ with an initial grain size of $22 \mu \mathrm{m}$, DRX is incomplete, as indicted by flow curves. It is interesting to note that the average dynamic recrystallization grain size is about $22 \mu \mathrm{m}$, which is the finest dynamic recrystallization grain among all the deformation conditions and nearly the same as the initial grain size. Therefore, when the initial grain size is very small, the microstructure reconstituted by DRX will not be refined. It appears that the smallest dynamic recrystallization grain size exists for $25 \mathrm{Cr} 2 \mathrm{Ni} 4 \mathrm{MoV}$ steel, which is about $22 \mu \mathrm{m}$.

Table 2: Average dynamic recrystallization grain sizes $\left(D_{\mathrm{drx}}\right)$ for all deformation conditions

\begin{tabular}{|c|c|c|}
\hline $\begin{array}{c}\text { Temperature } \\
(\mathrm{K})\end{array}$ & $\begin{array}{c}\text { Strain rate } \\
\left(\mathrm{s}^{-1}\right)\end{array}$ & $\begin{array}{c}\mathrm{D}_{\mathrm{drx}}(\mu \mathrm{m}) \text { for } \\
22 / 1970 \mu \mathrm{m}\end{array}$ \\
\hline \multirow{4}{*}{1373} & 0.005 & $47.9 / 61.9$ \\
\cline { 2 - 3 } & 0.05 & $38.0 / 45.2$ \\
\cline { 2 - 3 } & 0.5 & $22.0 / 37.1$ \\
\hline \multirow{4}{*}{1423} & 0.005 & $88.0 / 91.4$ \\
\cline { 2 - 3 } & 0.05 & $49.2 / 50.2$ \\
\cline { 2 - 3 } & 0.5 & $27.5 / 29.7$ \\
\hline \multirow{4}{*}{1473} & 0.005 & $103.8 / 151.1$ \\
\cline { 2 - 3 } & 0.05 & $63.8 / 97.1$ \\
\hline \multirow{4}{*}{1523} & 0.5 & $33.2 / 58.0$ \\
\hline & 0.005 & $155.5 / 157.6$ \\
\cline { 2 - 3 } & 0.05 & $41.4 / 100.5$ \\
\cline { 2 - 3 } & 0.5 & $40.6 / 60.3$ \\
\hline
\end{tabular}

\subsection{DRX kinetics}

Two methods were used to calculate the DRX fraction. One is measuring the DRX fraction from the microstructure observation, which requires a large number of specimens and accurate identification of the new grains. The second one is computing from the stress-strain curves, which is simpler and quicker than a quantitative metallographic measurement. Therefore, in this study we used the second method to obtain the DRX fraction. The onset of DRX depends on the dislocation density and distribution during hot deformation. DRX occurs when the dislocation density or strain reaches a 


\section{YE et al.: EFFECTS OF GRAIN SIZE ON THE DYNAMIC RECRYSTALLIZATION OF 25Cr2Ni4MoV ...}

critical value. ${ }^{16}$ To simplify the Avrami analysis with an acceptable level of accuracy, the initiation of DRX was intentionally considered at the peak point and the effect of dynamic recovery on flow softening was not considered. Therefore, Equations (1) and (2) can be used to express the kinetics of DRX. ${ }^{17-19}$

$$
\begin{gathered}
X_{\mathrm{d}}=1-\exp \left[(-k)\left(\frac{\varepsilon-\varepsilon_{\mathrm{p}}}{\varepsilon_{\mathrm{p}}}\right)\right] \\
X_{\mathrm{d}}=\frac{\sigma_{\mathrm{p}}-\sigma}{\sigma_{\mathrm{p}}-\sigma_{\mathrm{s}}}
\end{gathered}
$$

where $X_{\mathrm{d}}$ is the DRX fraction, $k$ and $n$ are material constants, $\varepsilon_{\mathrm{p}}$ is the peak strain, $\varepsilon$ is the instantaneous strain, $\sigma_{\mathrm{p}}$ is the peak stress, $\sigma_{\mathrm{s}}$ is the steady stress and $\sigma$ is the instantaneous stress at different strains. Figure 8 shows the method used for determining the characteristic points of flow curves by using the work-hardening rate $(\theta=\mathrm{d} \sigma / \mathrm{d} \varepsilon)$. The peak and steady stress, and the peak and steady strain, were detected from the $\theta-\sigma$ curves and $\theta-\varepsilon$ curves. ${ }^{20}$ According to the flow curves, except for the incomplete deformation condition, all the flow
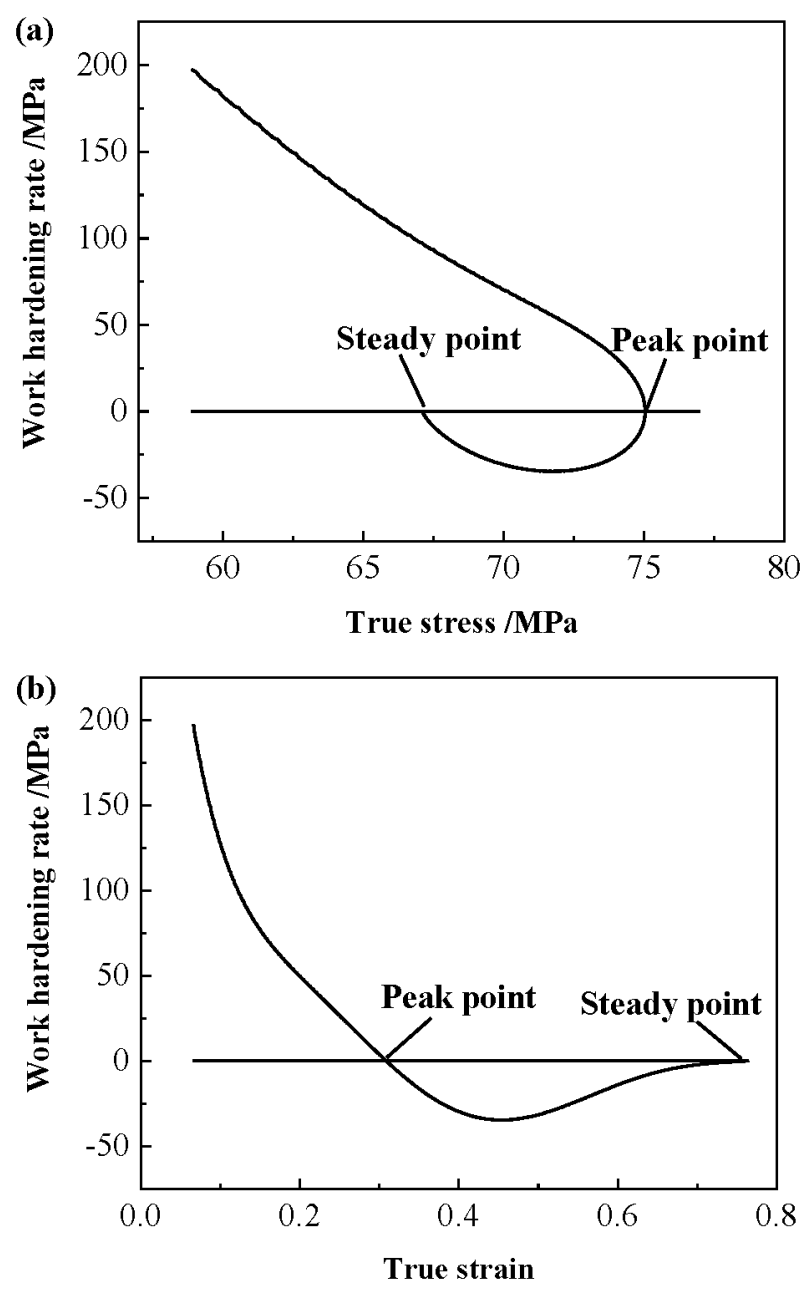

Figure 8: Determination of characteristic points of flow curves: a) characteristic stresses, b) characteristic strains curves were used to calculate the DRX fraction, which guarantees the accuracy of the DRX fraction model. Figure 9 shows the linear relationship between $\ln \left(-\ln \left(1-X_{\mathrm{d}}\right)\right)$ and $\left.\ln \left(\varepsilon-\varepsilon_{\mathrm{p}}\right) / \varepsilon_{\mathrm{p}}\right)$ under different deformation conditions. The values of $k$ and $n$ can be computed from the intercept and slope of the line. Therefore, for different initial grain sizes, the kinetics of DRX is given by:

$$
\begin{gathered}
X_{\mathrm{d}}=0 \quad \varepsilon<\varepsilon_{\mathrm{p}} \\
X_{\mathrm{d}}=1-\exp \left[-0.0122\left(\frac{\varepsilon-\varepsilon_{\mathrm{p}}}{\varepsilon_{\mathrm{p}}}\right)^{4.295}\right] \\
\varepsilon \geq \varepsilon_{\mathrm{p}} \text { and } d_{0}=22 \mu \mathrm{m} \\
X_{\mathrm{d}}=1-\exp \left[-0.363\left(\frac{\varepsilon-\varepsilon_{\mathrm{p}}}{\varepsilon_{\mathrm{p}}}\right)^{3.394}\right] \\
\varepsilon<\varepsilon_{\mathrm{p}} \text { and } d_{0}=1970 \mu \mathrm{m}
\end{gathered}
$$

Based on the calculated results, Figure 10 shows the DRX fraction variation with different initial grain sizes. The DRX fraction progresses in a sigmoidal manner with
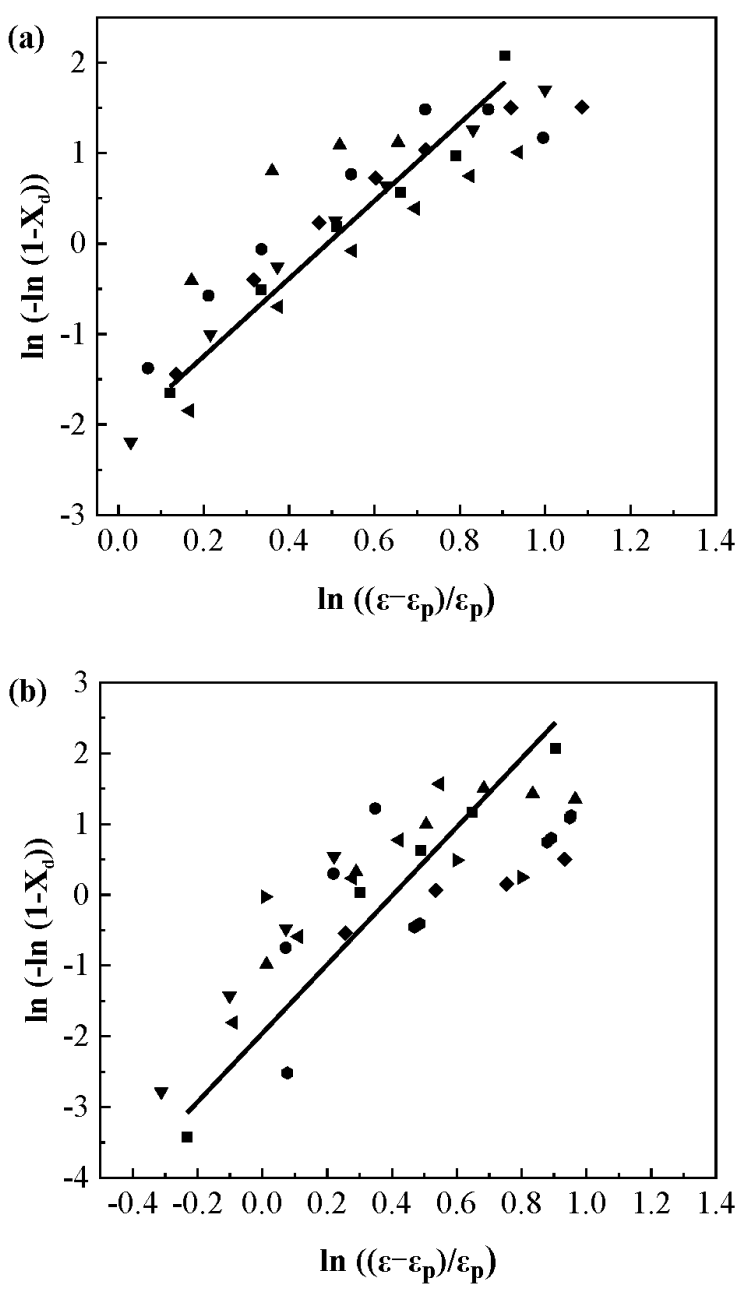

Figure 9: The linear relationship between $\ln \left(-\ln \left(1-X_{\mathrm{d}}\right)\right)$ and $\left.\ln \left(\varepsilon-\varepsilon_{\mathrm{p}}\right) / \varepsilon_{\mathrm{p}}\right)$ with different initial grain sizes: a) $22 \mu \mathrm{m}$, b) $1970 \mu \mathrm{m}$ 
L. YE et al.: EFFECTS OF GRAIN SIZE ON THE DYNAMIC RECRYSTALLIZATION OF 25Cr2Ni4MoV ...
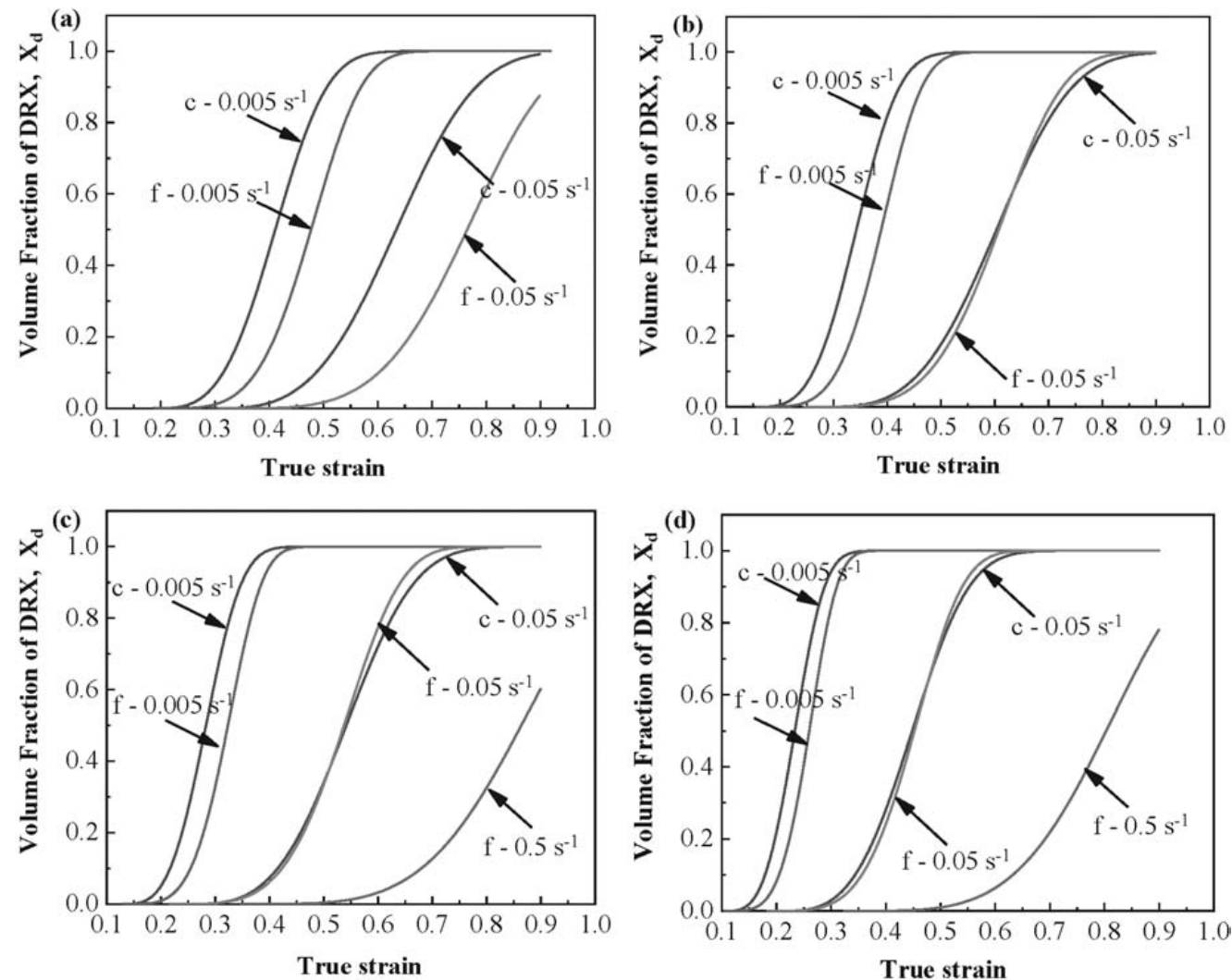

Figure 10: Volume fraction of DRX with different initial grain sizes at different deformation temperatures: a) $1373 \mathrm{~K}$, b) $1423 \mathrm{~K}$, c) $1473 \mathrm{~K}$, d) $1523 \mathrm{~K}$
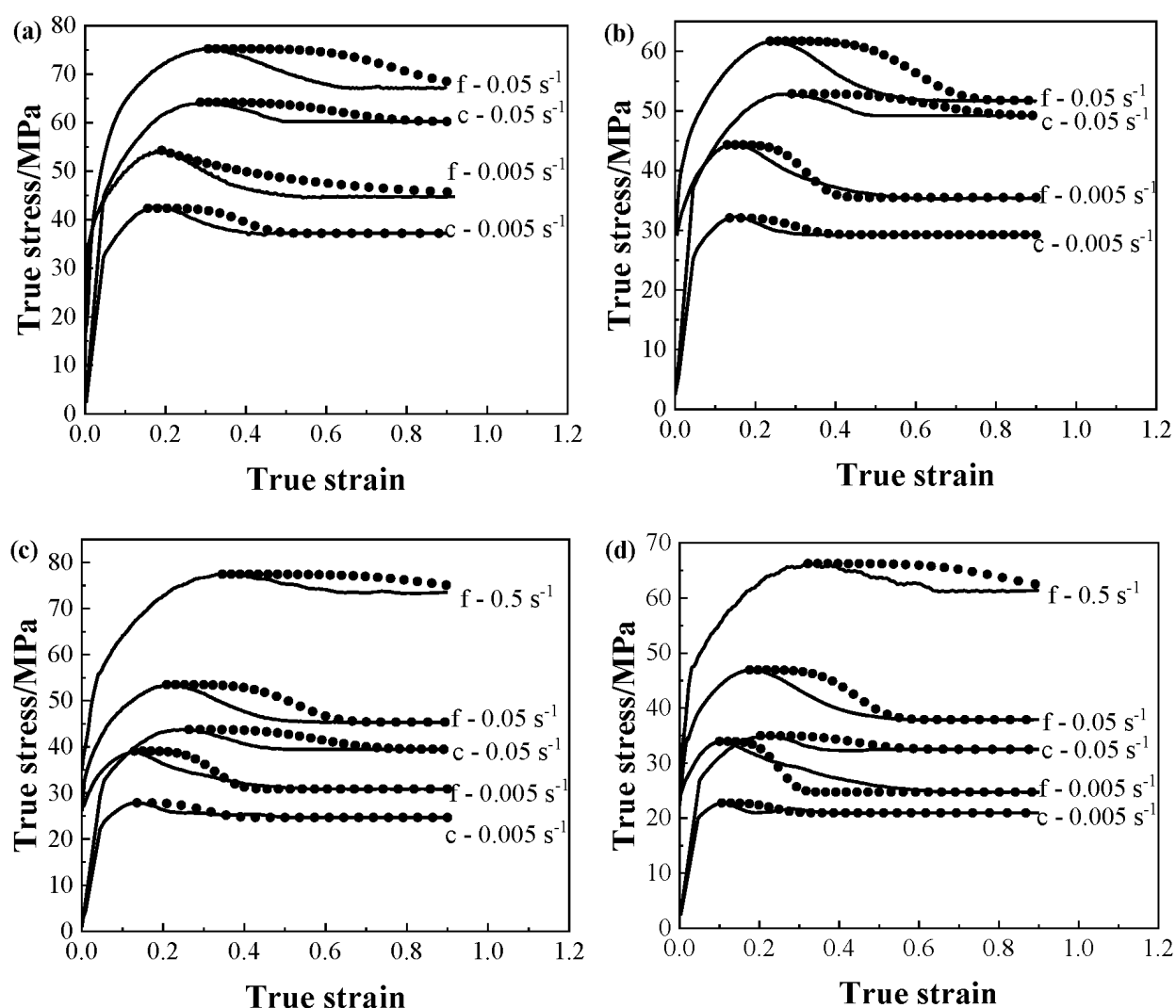

Figure 11: Comparison of fitting results and experimental results of flow curves after peak stress with different initial grain sizes at different deformation temperatures: a) $1373 \mathrm{~K}$, b) $1423 \mathrm{~K}$, c) $1473 \mathrm{~K}$, d) $1523 \mathrm{~K}$ 
respect to strain. The volume fraction of DRX increases with increasing strain. It can also be shown that the DRX fraction is higher at a lower strain rate or at a higher temperature for a certain strain. For all the deformation conditions, except the domain of $1423 \mathrm{~K} / 0.05 \mathrm{~s}^{-1}$, $1473 \mathrm{~K} / 0.5 \mathrm{~s}^{-1}$ and $1523 \mathrm{~K} / 0.5 \mathrm{~s}^{-1}$ with initial grain size of $22 \mu \mathrm{m}$, the volume fraction of DRX is $100 \%$ at low strain rates, which substantiates the stress-strain curves with a single peak in Figure 3. The DRX with an initial grain size of $1970 \mu \mathrm{m}$ occurs at a lower strain than that of $22 \mu \mathrm{m}$ at a strain rate of $0.005 \mathrm{~s}^{-1}$, which makes the former one have a higher DRX fraction at a certain strain. It is because the peak strain of the former is lower than that of latter. Therefore, combining the flow curves in Figure 3, the flow curves can well predict the volume fraction of DRX.

According to Equation (2) and (1), the flow stress beyond the peak stress could be derived:

$$
\left.\sigma=\sigma_{\mathrm{p}}-\left(\sigma_{\mathrm{p}}-\sigma_{\mathrm{s}}\right)\left\{1-\exp \left[-(k)\left(\frac{\varepsilon-\varepsilon_{\mathrm{p}}}{\varepsilon_{\mathrm{p}}}\right)^{n}\right\rceil\right]\right\}
$$

Figure 11 shows the fitting results and experimental results of the flow curves after peak stress for different initial grain sizes. The root mean square error (RMSE) as shown in Equation (7) was used to evaluate the ability of Equation (6) to predict flow stress. $P_{i}$ is the predicted value and $E_{i}$ is the experimental value. The RMSE for all flow curves is $2.30 \mathrm{MPa}$, which shows that the volume fraction of DRX is capable of predicting the flow curves after the peak stress.

$$
R M S E=\sqrt{\frac{1}{N_{i}} \sum_{i=1}^{N}\left(P_{i}-E_{i}\right)^{2}}
$$

\section{CONCLUSIONS}

By investigating the effects of grain size on the dynamic recrystallization of $25 \mathrm{Cr} 2 \mathrm{Ni} 4 \mathrm{MoV}$ steel, the microstructural evolution of $25 \mathrm{Cr} 2 \mathrm{Ni} 4 \mathrm{MoV}$ steel during DRX is clearer, which is very important for the design of an open-die forging process for a super-large nuclearpower rotor. The following conclusions are drawn.

The initial grain size strongly influences the microstructural evolution of $25 \mathrm{Cr} 2 \mathrm{Ni} 4 \mathrm{MoV}$ steel. At high temperature and strain rate, DRX of $25 \mathrm{Cr} 2 \mathrm{Ni} 4 \mathrm{MoV}$ steel with coarse grains is complete, while that of the alloy with fine grains is incomplete.

When the initial grain size is small, DRX will not refine the microstructure. The smallest dynamic recrystallization grain size of $25 \mathrm{Cr} 2 \mathrm{Ni} 4 \mathrm{MoV}$ steel is about $22 \mu \mathrm{m}$ with the deformation condition of $1373 \mathrm{~K} / 0.5 \mathrm{~s}^{-1}$ and initial grain size of about $22 \mu \mathrm{m}$.

The dynamic recrystallization fraction $\left(X_{\mathrm{d}}\right)$ can be given as

$$
X_{\mathrm{d}}=0 \quad \varepsilon<\varepsilon_{\mathrm{p}}
$$

$$
\begin{gathered}
X_{\mathrm{d}}=1-\exp \left[-0.0122\left(\frac{\varepsilon-\varepsilon_{\mathrm{p}}}{\varepsilon_{\mathrm{p}}}\right)^{4.295}\right] \\
\varepsilon \geq \varepsilon_{\mathrm{p}} \text { and } d_{0}=22 \mu \mathrm{m}
\end{gathered}
$$

The comparison of predicted results and experimental results shows that the volume fraction model of DRX for $25 \mathrm{Cr} 2 \mathrm{Ni} 4 \mathrm{MoV}$ steel can be used to predict the flow stress after the peak stress with an acceptable level of accuracy.

\section{Acknowledgement}

The authors appreciate the financial support from $\mathrm{Na}$ tional Science and Technology Major Project of China (Grant No. 2018ZX04044001).

\section{REFERENCES}

${ }^{1}$ N. Harris, D. Shahriari, M. Jahazi, Analysis of void closure during open die forging process of large size steel ingots, Key Engineering Materials, 716 (2016), 579-585, doi:10.4028/www.scientific.net/KEM.716.579

${ }^{2}$ P. H. Kim, M. S. Chun, J. J. Yi, Y. H. Moon, Journal of Materials Processing, 130-131 (2002), 516-523, doi:10.1016/s09240136(02)00798-7

${ }^{3}$ F. Chen, Z. S. Cui, S. J. Chen, Recrystallization of $30 \mathrm{Cr} 2 \mathrm{Ni} 4 \mathrm{MoV}$ ultra-super-critical rotor steel during hot deformation. Part I: Dynamic recrystallization, Materials Science and Engineering A, 528 (2012) 15, 5073-5080, doi:10.1016/j.msea.2011.03.008

${ }^{4}$ M. R. Barnett, A. G. Beer, D. Atwell, A. Oudin, Influence of grain size on hot working stresses and microstructure in $\mathrm{Mg}-3 \mathrm{Al}-1 \mathrm{Zn}$, Scripta Materialia, 51 (2014), 19-24, doi:10.1016/j.scriptamat. 2004.03.023

${ }^{5}$ A. Belyakov, K. Tsuzaki, H. Miura, T. Sakai, Effect of initial microstructures on grain refinement in a stainless steel by large strain deformation, Acta Materialia, 51 (2003), 847-861, doi:10.1016/ S1359-6454(02)00476-7

${ }^{6}$ C. X. Yue, L. W. Zhang, S. L. Liao, H. J. Gao, Mathematical models for predicting the austenite grain size in hot working of GCr15 steel, Computational Materials Science, 45 (2009), 462-466, doi:10.1016/ j.commatsci.2008.11.003

${ }^{7}$ Z. N. Yang, F. C. Zhang, C. L. Zheng, M. Zhang, B. Lv, L. Qu, Study on hot deformation behavior and processing maps of low carbon bainitic steel, Materials and Design, 66 (2015), 258-266, doi:10.1016/j.matdes.2014.10.068

${ }^{8}$ M. S. Chen, Y. C. Lin, X. S. Ma, The kinetics of dynamic recrystallization of 42CrMo steel, Materials Science \& Engineering A, 556 (2012), 260-266, doi:10.1016/j. msea.2012.06.084

${ }^{9}$ O. A. Zambrano, R. E. Loge, Dynamic recrystallization study of a $\mathrm{Fe}-\mathrm{Mn}$-Si based shape menmory alloy in constant and variable thermomechanical conditions, Materials Characterization, 152 (2019), 151-161, doi:10.1016/j.matchar.2019.04.016

${ }^{10}$ S. Y. Zhao, H. Q. Liu, G. Y. Lin, Y. L. Jiang, J. Xun, Dynamic recrystallization behavior of $\mathrm{Zr}-1 \mathrm{Sn}-0.3 \mathrm{Nb}$ alloy during hot rolling process, The Journal of The Minerals, Metals \& Materials Society, 70 (2018) 7, 1106-1111, doi:10.1007/s11837-017-2659-1

${ }^{11}$ W. Wang, J. Zhao, R. X. Zhai, R. Ma, Arrhenius-Type constitutive model and dynamic recrystallization behavior of $20 \mathrm{Cr} 2 \mathrm{Ni} 4 \mathrm{~A}$ alloy carburizing steel, Steel Research, 83 (2017) 3, 1600196, doi:10.1002/ srin. 201600196

${ }^{12}$ D. L. Sang, R. D. Fu, Y. P. Wang, Y. J. Li, Dynamic microstructure evolution and mechanism of Fe-38Mn alloy during hot shear-com- 


\section{YE et al.: EFFECTS OF GRAIN SIZE ON THE DYNAMIC RECRYSTALLIZATION OF 25Cr2Ni4MoV ...}

pression deformation, Materials Science \& Engineering A, 747 (2019), 130-135, doi:10.1016/j.msea.2018.12.059

${ }^{13}$ W. Wang, R. Ma, L. P. Li, R. X. Zhai, S. B. Ma, H. J. Yan, S. J. Zhang, S. Y. Gong, Constitutive analysis and dynamic recrystallization behavior of as-cast 40CrNiMo alloy steel during isothermal compression, Journal of Materials Research and Technology, 747 (2019), 130-135, doi:10.1016/j.msea.2018.12.059

${ }^{14}$ Y. K. Xu, P. Birnbaum, S. Pilz, X. C. Zhuang, Z. Zhao, V. Krausel, Investigation of constitutive relationship and dynamic recrystallization behavior of $22 \mathrm{MnB} 5$ during hot deformation, Results in Physics, 14 (2019), 102426, doi:10.1016/j.rinp.2019.102426

${ }^{15}$ P. Zhou, Q. X. Ma, Dynamic recrystallization behavior and constitutive modeling of as-cast $30 \mathrm{Cr} 2 \mathrm{Ni} 4 \mathrm{MoV}$ steel based on flow curves, Metals \& Materials International, 23 (2017) 2, 359-368, doi:10.1007/s12540-017-6538-7

${ }^{16}$ P. Y. Zhao, Y. Z. Wang, S. R. Niezgoda, Microstructural and micromechanical evolution during dynamic recrystallization, International
Journal of Plasticity, 100 (2018), 52-68, doi:10.1016/j.ijplas.2017. 09.009

${ }^{17}$ M. H. Wang, Y. F. Li, W. H. Wang, J. Zhou, A. Chiba, Quantitative analysis of work hardening and dynamic softening behavior of low carbon alloy steel based on the flow stress, Materials and Design, 45 (2013), 384-392, doi:10.1016/j.matdes.2012.08.041

${ }^{18} \mathrm{H}$. Mirzadeh, A. Najafizadeh, The rate of dynamic recrystallization in 17-4 PH stainless steel, Materials and Design, 31 (2010) 10 , 4577-4583, doi:10.1016/j.matdes.2010.05.052

${ }^{19}$ Z. Y. Zeng, L. Q. Chen, F. X. Zhu, X. H. Liu, Dynamic recrystallization behavior of a heat-resistant martensitic stainless steel 403Nb during hot deformation, J. Mater. Sci. Technol., 27 (2011) 10, 913-919, doi:CNKI:SUN:CLKJ.0.2011-10-009

${ }^{20}$ B. Gong, X. W. Duan, J. S. Liu, J. J. Liu, A physically based constitutive model of as-forged 34CrNiMo6 steel and processing maps for hot working, Vacuum, 155 (2018), 345-357, doi:10.1016/j.vacuum. 2018.06.022 